\title{
Holmes ON LAW AND MORALITY
}

\section{MARK STRASSER}

This article explores Justice /lolmes position on the relationship befween law and morality: and discusses some of the mistaken interprefutions of hat position. Commentators claims to the contrary notwithstanding. Holmes 'predictive theon oflaw and his discussion of the "bad man" do not illustrake the separation benve'n law and moraling bu merely that lanjful actions need not be performed for morally. praiseworthy reasons and that positive law and moraling do not always coincide. He suggested hat the conflotion of law and moralisy might be reduced by changing legal keminology so that moral and legal terms would not overlap, a proposal with possible drawbacks that llolmes did mor seem to appreciate. That said, however, defractors overestimate the exient ro which llolmes asserfed that hn and noraling should be distinguished, thereby distorting both Holmes' views and the value of his insights.
Cut aricle explore la position du juge Holmes sur la relation entre la loi a la moralite et iraife de certaines inferprifations errones à ce sujet. Nomolbstant les revendications comtraires des commentatems. la theioric predictive de droit de llolmes el sa discussion sur a les mechants " n illusirem pas la séporation entre le droit ef la moralite. mais simplement que les actions liciles ne doiven pas itre cxeculées pour des raisons moralement louables of que le droit positif et la moralité ne wom pas toujours de pair. II suggère qu' en changeam la rerminologie juridique de sorte que les termes juridigues et moranx ne se chevancherdien pas. fe droit ef la moraline seraicul alom moins apparics. the suggestion qui préscute des inconveniens evennels que lloimes n'a pas semble oppricier. Ceci dit. les defrociems surestimen towrefois la mesure dans launelle llolmes a affirmé qu'il fallait distinguer le droit de la moralité. faussant par conséquent les points de ime de Holmes et la valeur de ses idèes.

\section{TABLE of Contents}

I. Introduction . $\ldots \ldots \ldots \ldots \ldots \ldots \ldots \ldots \ldots \ldots \ldots \ldots$

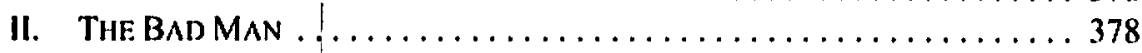

A. Holmes' Understanding of the LAw . . . . . . . . . . . . 379

B. ON FINES verSUS TAXES . . . . . . . . . . . . . . . . 380

C. What About the Bad Man Makles Him Bad? . . . . . . . . . . 382

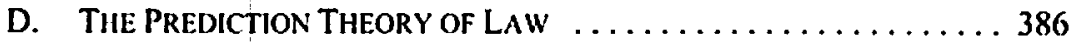

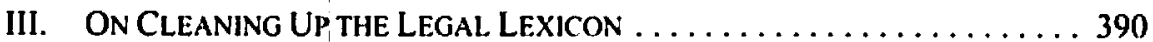

A. The Separation of Law and Moral. $\ldots \ldots \ldots \ldots \ldots \ldots$

B. Moral versus Legal DUties . . . . . . . . . . . . . . . . . . 392

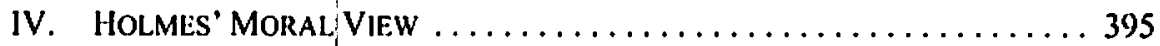

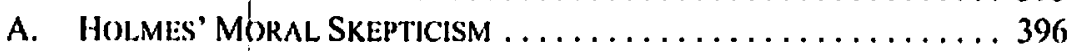

B. Hol.Mes' Moral Critiqul: . . . . . . . . . . . . . . . . . . 397

V. Conclusion ......................... 401

Trustees Professor of Law, Capital University Law School, Columbus, Ohio. I would like to thank Professors Mark Brown, James Beattie, and the anonymous reviewers of the Alberfa Law Review for their helpful comments on earlier drafts of this article. 


\section{INTRODUCTION}

Justice Oliver Wendell Holmes is one of the most cited and discussed United States Supreme Court Justices in American history.' As is perhaps true of all influential thinkers, however, Holmes also has his detractors - in particular, for his alleged moral nihilism. ${ }^{2}$ While these detractors are correct that Holmes denies that there is an objective universal morality, they are incorrect about the implications of his moral position for his analysis of the law. This article will explore some of the mistaken interpretations of Holmes' position and offer an explanation of his position that makes it both more plausible, and more useful, in understanding the relationship between law and morality.

\section{The BAD MAN}

Holmes famously suggested that the law should be viewed through the eyes of a bad man. Commentators disagree about both what Holmes was saying and why he was saying it. Those disagreements are due at least in part to differing emphases on the context in which his comments were first made public, and in part to a failure to pay sufficiently close attention to what he said. When that context is examined more closely and considered in light of Holmes' letters and other works, many of the current Holmes interpretations will be seen to be not only implausible, but also incapable of capturing Holmes' insights about the law. Holmes' actual view is much more respectful of morality than is currently appreciated, and is quite compatible with a range of views about the nature of morality and its connection to law.

1 Sec, e.g., Morton J. Honwil, The Transformation of American Law 1870-1960: The (risis of Legal Orthodoxy (New York: Oxford University Press, 1992) at 109 ("Oliver Wendell Holmes, Jr., [was] the most important and influential legal thinker America has had"); Richard A. Posner. ed.. The Essential Holmes (Chicago: University of Chicago Press, 1992) at ix [Posner, The Essemial Holmes] ("Oliver Wendell Holmes is the most illustrious figure in the history of American law"); Fred R. Shapiro. "The Mosi-Cited Legal Scholars" (2000) 29 J. Leg. Stud. 409 al 424 (listing Holmes as one of the most-cited legal scholars); James Knudson, "The Influence of the German Concepts of Volksgeist and Zeiggeist on the Thought and Jurisprudence of Oliver Wendell Holmes" (2002) II J. Transnat'I L. \& Pol'y 407 at 407 ("Justice Oliver Wendell Holmes is perhaps the most famous and influential judge in American legal history"); Morris B. Hoffman, Book Review of Law Without Values: The Life, Work and legacy of Justice Holmes by Albert W. Alschuler (2001) 54 Stan. L.. Rev. 597 at 598 ("No other American legal figure has ever had more written about him than Holmes"); and Morton J. Horwitz. "The Place of Justice Holmes in American Legal Thought" in Roben W. Gordon. ed.. The l.egacy of Oliver Wendell /lolmes. Jr. (Stanford: Stanford Universily Press, 1992) 31 at 31 (Horwily, "The Place of Justice Holmes"] ("THERE HAS BI:F.N only one great Anerican legal thinker and it was Holmes").

: See Albert W. Alschuler, Law Wihnom Vahes: The Life. Work, and Legacy of Justice Holmes (Chicago: University of Chicago Press, 2000) at 10 ("Holmes was at the forefront of ... a revolt against objective concepts of right and wrong"); Stephen 13. Presser, "Somt Thoughts on Our Present Discontents and Duties: The Cardinal, Oliver Wendell Holmes, Jr., the Unborn. the Senate, and Us" (2003) I Ave Maria L. Rev. 113 at 118 ("Holmes probably was not the Antichrist, but he surely gave the Prince of Darkness a run for the money"); and David Luban, "Justice Ilolmes and the Metaphysics of Judicial Restraint" (1994) 44 Duke L.J. 449 at 475 ("Holmes qualifies as a moral nihilist") [Luban, "Judicial Restraint"]. 


\section{A. Holmes' UNDERSTANDing OF THE LaiW}

In 1897, Holmes gave an address at the dedication of a new hall at the Boston University School of Law. ${ }^{3}$ One of his goals was to help students undertake "a right study and mastery of the law as a business with well understood limits, a body of dogma enclosed within definite lines." To make the law's limits clear, he offered an heuristic to separate law from the provinces of morality and social convention:

If you want to know the law and nothing else, you nust losk at it as a bad man, who cares only for the material consequences which such knowledge enables him to predict. not as a good one, who finds his reasons for conduct, whether inside the law or outside of it, in the vaguer sanctions of conscience.

Holmes offers the example of the bad man because, as Posner points out, such an individual is not motivated by his conscience to act rightly. ${ }^{\text {T }}$ Yet, Holmes is not thereby suggesting that such an individual is likely to be a law-breaker - "a bad man has as much reason as a good one for wishing to avoid an encounter with the public force." Indeed, if we were only to use external behaviour as our guide, we might have great difficulty in determining who deserved moral praise, since a "man who cares nothing for an ethical rule which is believed and practised by his neighbors is likely nevertheless to care a good deal to avoid being made to pay money, and will want to keep out of jail if he can." ${ }^{-8}$ While the bad man does not act based on "principles of ethics or admitted axioms," "but instead in light of what the "courts are likely to do in fact," ${ }^{10}$ he nonetheless will abide by the law as a matter of self-interest.

At first glance," it might seem as though Holmes' bad man is simply the paradigmatic self-interested man. ${ }^{12}$ Yet, there are a variely of reasons that such a description of the bad man is inaccurate, if only because he may not be sufficiently self-interested. For example, there is no mention of the bad man's wanting to know the likelihood of his being punished even were he to break the law - he might avoid punishment by escaping detection, ${ }^{13}$ bribing

The address, delivered at the dedication on 8 January 1897, was later published in the /honard Law Review. See Oliver Wendell Holmes, "The Path of the Law" (1897) 10 Harv. L. Rev. 457 at 457. n. I [Holmes, "The Path of the Law"].

lbid. ut 459.

lbid.

See Posner, supra nole 1 al xi (discussing "Ihe "bad man' theory of law (law viewed from the standpoint of persons who care nothing for moral duly)").

Supra note 3 at 459.

lhid.

Ibid. at 460 .

lbid. at 461 .

Sanford Levinson \& J.M. Balkin, "The 'Bad Man.' the Good, and the Self-Reliant" (1998) 78 B.U.L. Rev. 885 at $886-87$ ("At first glance, the image of the "bad man' seems perlectly clear. He is a version of the ideal-type of homo economicus interested only in maximixing his own individual preferences, indifferent to others except insolar as they serve as material obstacles to fullilling egoistic desires").

Sec Robert W. Gordon, "The Path of the Lawyer" (1997) 110 Harv. L. Rev. 1013 at 1014 (suggesting that on one view, "the "bad man" is just the rational man - Homo law-amd-ecomomicus - who treats all legal rules as prices on conducl").

Jack M. Beermann, “Holmes’s Good Man: ^ Comment on Levinson and Balkin" (1998) 78 B.U.L. Rev. 937 at 944 (noting that "in addition to the reaction of the courts, the bad man is likely to take into account the probability of detection when deciding whether to obey the law"). See also Alschuler. supra 
or blackmailing a judge, erc. Indeed, some commentators seem to believe that Holmes' bad man is not bad enough because of his failure to consider that he might escape justified sanctions due to the legal system's inefficiencies. ${ }^{14}$

\section{B. ON Fines versus TAXes}

Even if one brackets the possibility that a wrongdoer will be able to escape justified punishment, Holmes' picture of the bad man still scems incomplete, as becomes clear when one considers Holmes' differentiation between paying taxes and fines. Holmes notes that from the perspective of the bad man, duty mainly means "a prophecy that if he does certain things he will be subjected to disagreeable consequences by way of imprisonment or compulsory payment of money."'s By talking about duty in this way, Holmes does not provide a ready way to distinguish between two different types of compulsory payments fines and taxes. ${ }^{16}$ Given that fines tend to be exacted when one has done something illegal whereas taxes will be exacted when one has done something such as earning a salary, Holmes might seem to have overlooked something important.

Holmes understands that he has not provided a way to distinguish between these types of payments, and offers an analysis of whether it would matter to a bad man if he were "being fined [or] ... being taxed a certain sum for doing a certain thing." ${ }^{17}$ In the bad man's view, it "does not matter, so far as the given consequence, the compulsory payment, is concerned, whether the act to which it is attached is described in terms of praise or in terms of blame, or whether the law purports to prohibit it or to allow it." Basically, Holmes is suggesting that if the consequences are the same whether the bad man pays a $\$ 100$ tax or a $\$ 100$ penalty, the bad man will be indifferent between those two possibilities. The bad man will only have a preference if "in one case and not in the other some further disadvantages, or at least some further consequences, are attached to the act by the law."19

Yet, Holmes' bad man seems to ignore disadvantages and adverse consequences that others would consider. For example, an individual who is fined $\$ 100$ rather than paying that amount in taxes might suffer in the eyes of his fellow citizens. Perhaps those individuals would be less likely to patronize his business or socialize with him or his family. Even the bad man would care about effects like that. Just as one might argue that Holmes fails to consider that the selfish man would want to know about the probability that he would not be prosecuted or convicted notwithstanding an express statutory prohibition, one might argue that Holmes seems not to have considered that the selfish man would be interested in knowing about external sanctions that might be imposed against him even if those sanctions would not be imposed by the state. For example, sanctions imposed by members of society might affect the bad man's enjoyment of life or his ability to earn an income.

note 2 at 145 (suggesting that the bad man would really be concerned about what the sherifr would do). See Becrmann, ibid.

Stupra nole 3 at 461.

Ste, e.g., David Luban. "The Bad Man and the Good Lawyer: A Centenuial Essay on Holmes's The Path of The Law" (1997) 72 N.Y.U.L. Rev. 1547 at 1565 [Luban, "The Bad Man and the Good Lawyer"].

Stupra nole 3 at 461.

thid.

thid. 
When discussing Holmes' bad man, Posner suggests that the bad man would take all of these factors into account:

Many people obey the law because they would not profit from breaking it cien if there were no formal sanctions - they are restrained by habit. conscience (insofar as law tracks morals, as it frequently does), concern with reputation or other considerations of reciprocity, lack of net expected gain when risks and oppontunity costs are taken into account, or sympathy or atfection for the potential victims of their wrongdoing."

Yet, Posner's bad man considers a variety of factors Holmes' bad man does not. Holmes says that the bad man would be indifferent between paying a tax and paying a fine unless "in one case and not in the other some further disadvantages, or at least some further consequences, are attached to the act by the law."21 This means that unlike the Posnerian bad man, the Holmesian badiman would be indifferent between paying a fine and paying a tax where no further legal consequences were attached to that decision, even if other non-legal consequences would attach to that decision.

In commenting on Holmes' bad man theory of law, Judge Posner suggests that Holmes' "conception overlooks the people who obey the law because it is the law."22 However, Posner argues, the "oversight may not be critical"23 because there "may not be many "good men' in the specific sense of people who comply with laws merely out of respect for law, a felt moral obligation to obey it." 24 Yet, Holmes does not overlook that there are individuals who obey the law because it is law. On the contrary, Holmes discusses the good man "who finds his reasons for conduct, whether inside the law or outside of it, in the vaguer sanctions of conscience."2s

It is worth exploring why the Holmesian bad man only considers the legal consequences of his act. Holmes discusses the bad man - someone not motivated by conscience precisely because he believes that many (good) individuals are motivated by their consciences to act in accord with law. ${ }^{26}$ Because such individuals might act rightly whether or not the law requires them to do so, ${ }^{27}$ it might be difficult to ascertain in a given instance whether an individual acted properly because of the law rather than because of morality. By the same token, Holmes wants to remove from consideration the effects of social opinion on the individual's calculation about whether to obey the law because, otherwise, it would be difficult to tell whether the individual was motivated to obey the law because of the legal

Richard A. Posner, The Problems of Jurisprudence (Cambridge. Mass.: Harvard University Press, 1990) at 223-24 [Posner. The Problems of Jurisprudence].

Supra note 3 at 461 [emphasis added].

See Posner. The Problems of Jurisprudence, supra note 20 at 223 [(cmphasis in original].

lbid.

lbid.

See Holmes, "The Path of Law," supra note 3 at $45 \%$.

See ibid. (discussing the good man "who finds his reasons for conduct, whether inside the law or outside of it, in the vaguer sanctions of conscience").

27 See Erin Rahne Kidwell, "The Paths of the Law: Ilistorical Consciousness, Creative Democracy, and Judicial Review" (1998) 62 Alb. L. Rev. 91 at 114 ("cthical individuals will behave correctly regardless of whether legal consequences ensue or not"). 
sanctions that might otherwise be imposed or, instead, because he valued his neighbours' business or their opinion of him.

Holmes' focus on the legal consequences of actions is why he has to exclude from consideration both sanctions of conscience (corresponding to the consequences of moral wrongdoing) and the social opprobrium that might be associated with law-breaking. Holmes' bad man only considers the effects of the law, ${ }^{28}$ notwithstanding that a purely self-interested individual would consider other eflects on his own well-being as well."9

Posner notes that "[m]any people obey the law because they would not profit from breaking it even if there were no formal sanctions." ${ }^{30} \mathrm{He}$, too, recognizes that an individual might be motivated by a variety of concerns to act in the way required by law. Basically, both he and Holmes offer pictures involving two people: (1) the "bad" man who acts in light of the legal consequences; and (2) the "good" man who acts in light of a variety of other considerations. Yet, the "good" man might be acting in light of many non-moral considerations, such as the possibility that his acting poorly will cause his neighbours to shun him, and it is not at all clear that the man who acts to avoid adverse legal consequences is any worse (morally or otherwise) than the man who acts to avoid adverse non-legal consequences. Further, even good people might want to know about the legal consequences of acting in particular ways, especially because the law may not permit one to follow the morally preferable course of action. ${ }^{31}$

\section{What about the Bad Man Makes Him Bad?}

Il' the bad man's wanting to know the practical implications of the law is not itself worthy of condemnation, then it may be helpful to ligure out the sense in which he is appropriately labeled "bad." Indeed, there has been some confusion about why Holmes describes him as bad, which is due at least in part to a misunderstanding of Holmes' project.

Consider the view that good and bad individuals are distinguishable in that the former but not the latter acts rightly out of a recognition that it is their duty to do so..$^{32}$ According to this view, good individuals neither follow the law because they fear the imposition of sanctions such as a fine or imprisonment, nor because they fear the sanctions of conscience. Instead, they act rightly without considering the benefits of doing so or the costs of failing to do so.

:x Supra note 3 at 461 (noting that the bad man would treat a tax and a fine differently only if the one and not the other had disadvantages or consequences "attached to the act by the law").

20 It is for this reason among whers that it is not accurate to say that Holmes" bad man is simply the Hobbesian man. See Siephen R. Perry, "Holmes versus Hart: The Bad Man in Legal Theory" in Steven J. Burton, ed., The Pah of the Law and is lwhence: The Legacy of Oliver Wendell Ilolmes, .J. (New York: Cambridge University P'ress, 2000) 158 at 179 (pointing out that "Holmes never discusses a realistic calculus of self-inlerest"). Professor Perry realizes that the had man is not a realistic selfinterested individual, but does not seem to appreciate how this undercuts the suggestion that the bad man is simply the Hobbesian man. Sec ibid. at 173 (suggesting that "the best overall interpretation of the bad man is the llobbesian view that he is the human archetype").

wo Supra note 20 at 223.

" For a discussion of immoral laws, sec infra notes $79-80$ and accompanying text.

3: $\quad$ See Posner, The Problems of Jurisprudence, supra note 20 at 223 (noting that there "may not be many 'good men' in the specific sense of people who comply with laws merely out of respect for law. a tielt moral obligation to obey it"). 
In contrast, bad individuals act rightly only after a consideration of the pains that might follow from non-compliance. Some commentators seem to believe Holmes discusses the bad man as a way of proposing that this is the difference between good and bad individuals.

Commentators are correct when suggesting that the Holmesian bad man obeys the law only because he fears the imposition of legal sanctions. ${ }^{31}$ Nonetheless, the bad man is not bad because he is willing to decide whether to obey the law out of a prospective calculation of pains and pleasures, since the Holmesian good man follows the law because he fears that his own conscience would punish him unmercifully were he to do otherwise. ${ }^{34}$ On Holmes' view, the fact that both the good and the bad man act out of a prospective calculation of pains and pleasures does not undercut the difference between them. ${ }^{35}$ The two are to be distinguished in that the bad man's conscience (unlike the good man's) does not play its proper role - it may fail to specify properly which actions are right and which are wrong, or it may fail to impose sanctions for the performance of bad actions. ${ }^{36}$

Commentators have proposed a variety of theories to explain why Holmes discusses the bad man. Professor Grey discusses and ultimately rejects the suggestion that Holmes' "deployment of the figure of the "bad man' implies that while morality is for good people, law is only for bad people." ${ }^{37}$ Such a view should be rejected. Holmes is using the bad man to illustrate how the law itself promotes good behaviour, which can only be done if the influences of public opinion and conscience are bracketed.

Professor Twining suggests that "the 'bad man' was introduced for quite limited purposes ... to dramatize a distinction between law and morals - the badness or amoral aspect, and

"S Se Kidwell, suprónole 27 at 113-14 "The "bad man' is an unethical individual who only behaves out of a fear of being punished by the law. This perspective is more useful than that of the 'good man.' because ethical individuals will behave correctly regardless of whether legal consequences ensue or not.").

34 Holmes, "The Path of the Law," supra note 3 at 459 (Holmes discusses the good person "who finds his reasons for conduct, whether inside the law or outside of it, in the vaguer sanetions of conseience"); Luban. "The Bad Man and the Good Lawyer," stura note 16 at 1564 ("Holmes means to contrast the bad man nol just with someone who takes all his cues from the law, but with sonteone who is guided by conscience outside as well as inside the law. In short, Holmes's "good man' is the man of conscience. and Holmes's "bad man" is not.").

35. Becrmann, supra note 13 at 939-40:

[Levinson \& Balkin], however, develop a second reading of Ilolmes's passage which is at odds with the notion that the good man obeys law out of at least a prima lacie ethical duty to do so regardless of the consequences. [Levinson \& Balkin] locus on llolmes"s phrase "vaguer sanctions of conscience" and state that Holmes oflers another reason lor the good man's obedience to the law, that the good man is "motivated by conscience" in the sense that "feclings of guilt or the fear of hellfire" are among the "sanctions" of conscience that motivate the good man to obedience. [Levinson \& Balkin] recognize that this reading reduces the diflerences between the good man and the bad man. Now both are motivated by the desire to avoid sanctions, one material, the other spiritual.

Cf. William Twining, "The Batd Man Revisiled" (1973) 58 Cornell L. Rev. 275 at 282 ("The difference between the Bad Mann and the Good Citizen does not rest on the latler's indifference to prediction, but on the former's indifference to morality").

" Thomas C. Grey, "Plotting The Path of the Lem" (1997) 63 Brook. L. Rev. 19 al 37 [Grey, "Plotting"]. Grey rejects this because he believes that Holmes uses the bad man for a limited purpose. See ibid. at 55 ("Holmes has made it explicit that the "bad man's' perspective is adopled for a limiled purpose, that of learning the rules and forcing the student and lawyer to locus on what those rules actually provide by way of remedy ). 
... to focus attention on a more realistic standpoint for law students than that of appellate judges - the predictive aspect." bad man illustrates the distinction between law and morals and the sense in which the predictive aspect is more relevant for law students and practicing lawyers than for appellate judges.

Holmes' bad man fulfills his duty and acts rightly, although perhaps for the wrong reason. Yet, that means that Holmes' use of the bad man does not illustrate the amorality of the law since the bad man performs the right action, but merely that individuals might follow moral laws for non-moral reasons.

Suppose that in the country of Uprightland there is a constitutional requirement that the law mirror the existing morality. Whatever morality requires, permits, or prohibits is required, permitted, or prohibited by the Uprightland law as well. Further, when moral notions change, the law will change with them. There may well be Holmesian bad men in Uprightland who perform the morally and legally required action solely because they fear fines or imprisonment. Yet, ex hyporhesi, the Uprightland law mirrors the moral law. ${ }^{34}$ It is thus at best misleading to suggest that Holmes offers the example of the bad man to illustrate the separability thesis ${ }^{40}$ - namely, that there is no necessary connection between law and morality," since Holmesian bad men might live in Uprightland, notwithstanding that system's necessary connection between law and morality.

Insofar as Holmes' bad man illustrates the difference between law and morality, ${ }^{42}$ it is a difference that Holmes frequently cites but that commentators do not sufficiently emphasize - namely, the different roles played by the agent's intention and motivation in the moral as

William Twining, "Other People’s Power: The Bad Man and English Positivism. 1897-1997" (1997) 63 Brook. L. Rev. 189 at 204 (Twining. "Other People's Power").

34 We shall assume for the purposes of this example that there is one moral law that is knowable. But compare Robin West. "Natural Law Ambiguitics" (1993) 25 Conn. L. Rev. 831 at 835 (describing the positivist legal reactionary position "that "law is law" and that there simply is no coherent or knowable independent 'moral standard' against which the law can be judged").

Twining, "Other P'eople's Power," supra nole 38 at 222 ("Holmes's original intention was to use the "bad man' as a device to introduce a positivist and a realist perspective. It is a vivid way of illustrating the separability thesis, which was, and to this day remains, controversial."); Robert W. Gordon. "Law as a Vocation. Holmes and the Lawyer's Path" in Burton, supra note 29, 7 at 13 ("Probably the most common reading of the speech is that it sets forth a purcly positivist theory of the law-a deflated. demoralized, 'disenchanted" view (10 use Max Weber's term) of the legal system").

John C.P. Goldberg. "Style and Skepticism in The Path of the Law" (1997) 63 Brook. L. Rev. 225 at 242 discussing

the "separation" or "separability thesis" - the notion that law and morality bear no necessary connection - was offered as a means of distinguishing positivism from the natural law Iradition. which claims that, strictly speaking. there is no such thing as an "immonl law," only moral laws or inmoral excrcises of power.

See also Horwitz. "The Place of Justice Holmes," supra note I at 140 (‥'The Path of the Law" narks the first clear articulation of legal positivism- hat is, an insistence on a sharp distinction between law and morals - by any American legal thinker").

* H.L. Pohlman. Austice Oliver Wendell Ilolmes \& Utilitarian.Jurisprudence (Cambridge Mass.: Harvard University Press, 1984) at 161-62 ("Holmes no doubt was a positivist. To prevent any confusion of law with morality, Holmes advised the student to look upon law as a "bad man."”). 
opposed to legal assessment of her action. ${ }^{43}$ The law regards law-abiding conduct as right regardless of why the agent is following the law, whereas (Holmes suggests) an agent's action is morally good only if performed for the right reasons. ${ }^{+4}$ Included within those reasons is a fear of the imposition of pangs of conscience, since the "good man" acts because he fears "the vaguer sanctions of conscience."

See Oliver Wendell I lolmes. "The Common Law" in Sheldon M. Novick. ed., The Collected W'orks of Justice Holmes: Complete Public Writings and Selected Judicial Opinions of Oliver Wendell Holmes, vol. 3 (Chicago: University of Chicago Press, 1995) at 184 [1lolmes, "The Common Law"]:

Courts of equity have laid down the doctrine in terms which are so wholly irrespective of the actual moral condition of the defendant as to go to an opposite extreme. It is said that "when a representation in a matter of business is made by one man to another calculated to induce him to adapt his conduct to it, it is perfectly immaterial whether the representation is made knowing it to be untrue, or whether it is made belicving it to be truc. if, in fact. it was untrue."

See also ibid. at 197:

[A]s the law has grown, even when its standards have continued to model themselves upon those of morality, they have necessarily become external, because they have considered, not the actual condition of the particular defendant, but whether his conducl would hase been wrong in the fair average member of the comnunity. whom he is expected to equal at his peril.

A separate issue involves I lolmes' focus on what the agent might reasonably have been inferred to have intended rather than on what she subjectively intended. See ibid. at 183 ("The standard of what is called intent is thus really an external standard of conduct under the known circumstances"). The intention might help define what the agent was trying to do, e.g. help a person in need, rather than why she was trying to do it, e.g., out of duty.

See ibid. at 280-81 ("But, as has been said before in these lectures, although the law slarts from the distinctions and uses the language of morality. it necessarily ends in extemal standards not dependent on the actual consciousness of the individual"); and Pohlman, supra note 42 at 15 ("As Holmes understood it, morality dealt 'with the actual intemal state of the individual's mind'; the law dealt with the individual's external acts"). It is thus rather misleading to suggest that llolmes believes that the law has nothing to do with morality, as if the contents of the former have no connection to the contents of the latter. See (irant Gilmore, "Some Reflections on Oliver Wendell Holmes, Jr." (1999) 2 Green Bag 2d 379 at 387 (discussing "the proposition, which Holmes restated hundreds of times, that the law has no concern with marality. In his lecture on the criminal law he pointed out. with equanimity, that under the theory that he espoused we frequently end up punishing those who are guilty of no moral wrongdoing while letting those whose moral behavior is outrageous go free: all that counts is the convenience of the community."). Yet, this misrepresents Holmes in two respects: (I) Holmes" distinction between law and morality is focused on the agent's motivation: and (2) Holmes denies that law is reducible to any one thing, even the convenience (or utility) of society.

See Holmes, "The Path of the Law," supro note 3 at 45\%:

If you want to know the law and nothing else. you must look at it as a bad man, who cares only for the material condecuenees which such knowledge enables him to predict, not as a good one, who tinds his reasons for conduct, whether inside the law or outside of it. in the vaguer sanctions of conscience.

Cf. Levinson \& Balkin, sumra note II at 888:

As soon as we begin to unpack this lormula, however, somelhing very puzzling begins to happen. Holmes's "good man" starts to look increasingly like his "bad man," and his "bad man" increasingly resembles his tormulation of the "good man." Consider, for example, that Holmes uses the "semctions of conscience" to explain why the "good man" obeys the law. These "sanctions" prestumably range from feclings of guill to the feur of hell fire; and the "good man" can surely predict that they will descend upon him if he misbelaves. Thes. both I folmes"s "good man" and his "bad man" seem lo be defined in terms of responses to sanctions. Of course, we are not claiming that Holmes has aceurately described the nutivations of good and bad persons: rather. we are pointing out how impoverished his psychological model seems to be. Ilolmes's picture of the "good man" more resembles a persen driven by a dominating superego than a mature individual whose ego cun exercise at least some measure of autonomous rellection and judgment. In short, if a "bad man" is defined as one driven by the fear of punishment, the llolmesian "good man" is just a special case of his "bad man" - he is a "bad man" driven by the fear of sanctions existing outside the law. This may seem to be a play on words. but if so, it is one generated by Holmes's peculian choice of language. 
Professors Balkin and Levinson correctly infer from Holmes' comment about the vaguer sanctions of conscience that "the good person would not violate a just or morally binding law even if public authorities stopped punishing its violation or the courts were closed. ${ }^{216}$ From this they conclude that "for the [Holmesian] good person, law is something other than predictions of official behavior; instead, law is a norm that generates a feeling of obligation to obey it, regardless of the probability of state-enforced sanctions resulting from disobedience." Thus, Professors Balkin and Levinson believe that the Holmesian good person acts out of a recognition of a moral obligation to obey the law, whereas the Holmesian bad person acts out of a fear that sanctions would otherwise be imposed.

While correct in their analysis of the bad man, Professors Balkin and Levinson misunderstand the good man in a crucial respect, and seem to be committing exactly the kind of conflation that Holmes is trying to prevent. Holmes emphasizes the distinction between law and morality because he believes that it is too easy for the distinction between them to become blurred. He notes that the "law is full of phraseology drawn from morals, and by the mere force of language continually invites us to pass from one domain to the other without perceiving it, as we are sure to do unless we have the boundary constantly before our minds." ${ }^{\text {+1 }}$ The interpretation offered by Professors Balkin and Levinson destroys the barrier that Holmes wishes to bolster. While many commentators discuss the moral obligation to obey the law, ${ }^{\text {t9 }}$ Holmes wishes to keep the domains of morality and law separate (to the extent that is possible) rather than provide an additional bridge between them.

The bad man does not illustrate that law and morality are separable in the way that many commentators claim. ${ }^{50}$ Bad men might live in a socicty or world in which there is a necessary connection between law and morality, where the contents of legal rules mirror the contents of moral rules. In such a society or world, the bad man might be as law-abiding and rightaction-performing as any good man in the society. Thus, Holmes' discussion of the bad man does not illustrate illegal or immoral action, or even that law and morality must diverge in content.

\section{The Prediction Theory of Law}

Holmes' prediction theory of law has received much negative criticism in the secondary literature, only some of which is deserved. While it is fair to suggest that Holmes' theory does not give as full an account of the law as some would desire, many commentators have understated the usefulness of Holmes' description and have misstated Holmes' purpose in offering this account of the law.

Levinson \& Balkin, ibid.

Ihid.

Holmes, "The Path of the Law," supra note 3 at 459-60.

See generally, Joseph Raz, "About Morality and the Nature of Law" (2003) 48 Am. J. Juris. I.

Cf. Posner, The Essential Holmes, supra nole 1 at xi (discussing "the severance of law from morals ... that is a basic element of Holmes's jurisprudence"). 
Holmes suggests that the "prophecies of what the courts will do in fact, and nothing more pretentious, are what I mean by the law." H1 Here, Holmes makes clear his sympathy for the bad man's view of law, $\$ 2$ which primarily focuses on knowledge of the law as a means of understanding and predicting the "material consequences" $" 53$ of particular courses of conduct.

Holmes' suggestion that the law can be reduced to prophecies about what the courts will do has been subject to a variety of criticisms. Professor Grey notes some of the difficulties for Holmes' approach insofar as it is purportedly offering "a scientific definition - one that might, for instance, identify the essence of the distinctively legal subset of social phenomena":54

The prediction theory fails to capture the legal attitudes of officials and probably of most ordinary citizens. attitudes that any reasonably complete sociological account of law must consider. It leaves out the element of perceived legitimacy, which seems a necessary aspect of any serious attempt to distinguish legal from other constraints as part of a gencral scientific study of society. Nor. for similar reasons. is it an adequate account of law from the peripective of the judge."

As Grey notes, however, Holmes was not attempting to offer a sociological account of the law. Rather, Grey argues, "Holmes proposed his prediction theory as a useful guideline for a particular and confined heuristic purpose, not as a general scientific or conceptual truth about the nature of law.":66

Grey believes that Holmes' purpose was relatively narrow because Holmes was addressing law students when he delivered "The Path of the Law" as a dedication. ${ }^{57}$ Yet, it is not at all clear that Holmes was solely emphasizing the importance of "learning the rules and forcing the student and lawyer to focus on what those rules actually provide by way of remedy," $"$ especially given Holmes' personal endorsement of the predictive theory of law and his clear sympathy for the bad man's view. Further, even if Holmes' purpose was somewhat narrow when delivering the dedication, his purposes might have been broader when he decided to publish the piece in the Harvard Law Review. Thus, had Holmes not published his remarks, his Boston University Law School address might more plausibly have been thought to have been designed to target law students (notwithstanding that addresses are sometimes delivered to one audience when the speaker has a different or more general audience in mind). However, Holmes' publication of the remarks in a law review whose readership is largely composed of legal professionals undercuts the persuasiveness and plausibility of the suggestion that the view expressed was only for law students. Further, Holmes' emphasis on what courts in fact do suggests that his goal was not to induce students and attorneys to focus on how the system is supposed to work. Finally, the explication offered here coheres with Holmes' other writings, further suggesting that the address and

Thomas C. Grey, “Holmes and Legal Pragmatism" (1989) 41 Stan. L. Rev. 787 at 828.

lbid.

lbid.

See Robert H. Bork; “The Judge's Role in Law and Culture" (2003) I Ave Maria L. Rev. 19 at 27.

Grey, "Plotting." stipra note 37 at 55. 
Holmes' focus on the bad man should not simply be dismissed as designed to get students and attorneys to learn legal rules and remedies. Yet, if Holmes was not addressing his theory only to law students but instead to those associated with the law more generally, then it might be helpful to consider some of the respects in which Holmes' predictive approach has broader relevance than one might have inferred from the analyses offered by many commentators.

Consider the criticism that Holmes' analysis has no relevance for the judge who of course will not be attempting to predict what she herself will do. ${ }^{3 y} \mathrm{Yet}$, judges might well be trying to predict whether their own opinions would be reversed on appeal ${ }^{\text {(t) }}$ rather than what they themselves will do. ${ }^{61}$ Even members of the United States Supreme Court might worry (or take comfort in the thought) ${ }^{62}$ that holdings will or might be overruled by future Courts. ${ }^{63}$

The claim here is not that the prediction theory captures the role of the judge ${ }^{\text {in }}$ in the same way that it captures the role of the practicing attorney. Judges debate whether they should rule in accord with established precedent or, instead, rule as they anticipate higher courts will rule where, for example, there is ample reason to believe that the higher court will overrule

Luban, "The Bad Man and the Good Lawyer," supra nole 16 at 1577.78:

[T]he prediction theory ... makes no sense at all from the point of view of a judge. Judges puzaled about the law of a case will nol answer their questions by predicting their own behavior, especially if the only basis for that prediction is their belief that the law is nothing but a prediction of their own belhavior. The problem is not that they can't get the prediction right, but rather that they can't get it wrong: any answer they come up with is the right answer. just because they have come up with it. If law is prophecies of what the courts will do, then court-made law consists of selffullilling prophecies.

C. Coalition for Econonic Equity : Wilson, 122 F.3d 692 at 717-18 (9th Cir. 1997) (Hawkins, Circuit

J.) (commenting on the denial of rehearing en bonc) discussing

the proper role of an inferior court faced with contrary, but apparently controlling, precedent that it honestly and eamestly believes will not be followed (or will be distinguished) by higher authority. Is it the role (the duty, if you will) of a court in that circumstance to attempl to accurately predict what the higher authorily will do? Or is its duty to laithfully follow existing precedent? If an inferior court in such a circumstance is free to predict what the higher court will do. then this panel probably got the issue right. If, however, the duty of a lower coun is to faithfully apply existing authority, then I have seen no persuasive argument that contradiets Judge Norris* Caroleme Products-Humer-Seatle analysis. no help to a judge who can hardly decide a case by prophesying what he himself will in fact do"). See Bowers v. Hardwick, 106 S. Ct. 2841 (1986) at 2856 (Blackmun, J., dissenting):

It took but three years for the Court to see the error in its analysis in. Minerswille School District v. Gobitis, 310 U.S. $586(1940)$... I can only hope that here, too, the Cour soon will reconsider its analysis and conclude that depriving individuals of the right to choose for themselves how to conduct their intimate relationships poses a far greater threat to the values most deeply rooted in our. Nation's history than tolerance of noneonformity could ever do. Bowers was overruled in Lawrence v. Texes, 539 U.S. 558 (2003).

4) Posner suggests that the predictive theory is accurale in at diflerent sense, namely, that judges of the highest eourt might try to predict how past judges would have decided the case (supwa note 20 at 224). Holmes did not offer his bad man example as a way of predicting court behaviour, notwithstanding commentators claims to the contrary. See, e.g., Anne C. Dailey, "Holmes and the Romantic Mind" (1998) 48 Duke L.J. 429 at 434 (suggesting that Holmes" "theory of the bad man lawyer was simply a heuristic device for predicting how courts will decide cases"). 
the existing precedent. ${ }^{\text {s5 }}$ Thus, although Holmes' predictive stance is not one that would be absurd for a judge to take, it is at best a controversial approach and might not be the central focus of many judges. ${ }^{\text {th }}$ It is much less controversial to suggest that an attorney should tell her client what the law requires, permits, and prohibits, which might well involve predicting when the public force would be used to impose sanctions upon the client.

Just as Holmes' prediction theory has implications for judges even if it does not offer a complete account of their roles, it also has implications for legislators, even if not accounting for all of a legislator's functions. ${ }^{77}$ Legislators should consider how statutes will be construed by courts if only to foreclose potential misunderstandings about the content or breadth of legislation. They also should consider whether a statute would be held unconstitutional when deciding whether to vote in favour of particular legislation. ${ }^{\mathrm{K}}{ }^{\mathrm{T}}$ Thus, there are a variety of ways in which the prediction theory is applicable to a variety of individuals connected with the law, even if it does not describe their functions exhaustively.

Certainly, Holmes' prediction theory does not offer a complete account of the judge's, the legislator's, or even the practicing attorney's roles. Holmes was well aware that attoneys advise their clients about more than legal matters, ${ }^{69}$ and an attorney advising a client about what is in her interest might well suggest that the client refrain from committing acts that, while harmful, might nonetheless escape legal sanction. Neither clients nor attorneys are solely interested in predictions about when the public force will be used, ${ }^{70}$ so Holmes' predictive theory does not even capture all that attorneys will be asked to do. ${ }^{71} \mathrm{Yet}$, Holmes' account was not meant to be exhaustive in its description of all of the functions performed by individuals associated with the law and thus should hardly be rejected out of hand for that reason.

Cf. Roper v. Simmons, 125 S.Ct. 1183 at 1209 (2005) (O'Connor, J., dissenting):

As a preliminary matter, I take issue with the Court's failure to reprove. or even to acknowledge, the Supreme Court of Missouri's unabashed refusal to follow our controlling decision in Sianford. The lower cour concluded that. despite Stanford's elear holding and historical recency, our decision was no longer binding authority because il was premised on what the court decmed an obsolete assessment of contemporary values. Quite apart from the merils of the constitutional question, this was clear error.

Sec Twining. "Other People's Power," supra note 38 at 201 ("It is diflicult to sece how any careful reader can altribute to Holmes the view that legislators, judges or advocales are centrally concerned with prediction").

ه: Holmes need not be elaiming that judges and legislators are centrally concemed with prediction. although he would suggest that it is something appropriately considered by them. Compare ibid. Sec, e.g., U.S., Cong. Rec., vol. 143, WL 125477 at H1202-05 (20 March 1997) (Rep. Conyers) ("I cannot support this (partial birth abortion) bill because it is unconstitutional").

Oliver Wendell Itolmes, "Just the Boy Wanted, In the Law, Youth's Companion" (7 February 1889) in Novick, supra note 43 at 339 [Holmes. "Just the Boy Wanted"|:

The lawyer's judgment is a sense of the relative imponance of facts with reference to the rules of

law, and a sense also, - the more the better, -- of their importance with regard to husiness, because law and business are bound together very closely. and in advising a man what to do the lawyer often needs to consider business consequences as well as law.

iv Posner does not seem to appreciale this. See Posner. The Problems of Jurisprudence, supra note 20 at 223 ("All [clients] want to know is whether the power of the state will comle down on them if they engage in a particular course of action").

" See Holmes, "Just the Boy Wanted," supra note 69 at $339-40$ (describing various roles that attorncys play). 
Holmes' discussion of the bad man and the predictive theory of law capture important elements of the law. They are not meant to establish that law must be separated from morality, although Holmes did have particular views about the ways in which law and morality were related. Those views are much less controversial than many commentators imply, since they merely deny that morality, when understood in a particular way, is necessarily embodied in the law.

\section{On Cleaning Up tile Legal Lexicon}

While commentators are incorrect to suggest that the Holmesian bad man illustrates the divergence between law and morality, they are correct that Holmes denies that the law mirrors morality. Indeed, Holmes emphasizes the dangers in failing to recognize this divergence and even suggests that much confusion would be avoided were legal terminology changed so that moral and legal terms did not overlap. Yet, this recommendation is offered to help clarify the law rather than denigrate morality. While Holmes' writing about morality is not always clear or even consistent, it is both unfair and inaccurate to suggest that he advocates moral nihilism or even skepticism. ${ }^{72}$

\section{A. The SEParation of Law and Morals}

While not offering the example of the bad man to illustrate that the law is amoral, ${ }^{73}$ Holmes nonetheless does suggest that there are important differences between morality and the law. Not only may the agent's motivation play different roles in moral as opposed to legal assessments, ${ }^{71}$ but moral rights and duties have different contents than do legal rights and duties.

Holmes notes that one of the

many evil effeets of the confusion between legal and moral ideas ... is that theory is apt to get the cart before the horse, and to consider the right or the duty as something existing apart from and independent of the consequences of its breach, to which certain sanctions are added afterwand. ${ }^{75}$

" See Holmes, "The Path of the Law," supra note 3 at $45 \%$ :

I take it for granted that no hearer of mine will misinterpret what 1 have to say as the language of cynicism. The law is the witness and extemal deposit of our moral life. Its history is the histury of the moral development ol the race. The practice of it, in spite of popular jests, tends to make good citizens and good men.

" Professor Weinberg does not seem to appreciate this. See Louise Weinberg. "Holmes' Failure" (1997) 96 Mich. L. Rev. 691 at 694 ("Morals are what is right; but law, according to The Path of the Law', is only the monetary penalty of which a "bad man' must keep clear").

4. Holmes noles that in some cases the law does take account of the agent's motivation in that an individual might not be liable but for his common law malice. See Oliver Wendell Holnes, "Privilege, Malice and Intent" (1894) 8 Harv. L. Rev. I at 2, as quoled in Novick, stupra note 43 at 372:

In some cases, he even may intend to do the harm and yet not have to answer for il; and, as I llink. in some cases of this latter sort, at least, actual malice may make him liable when without it he would not have been. In this connection I mean by malice a malevolent motive for action, without reference to any hope of a remoter benefit to oneself to be accomplished by the intended harm to another.

" Holmes, "The Path of the L.aw," supra note 3 at 458. 
Here, Holmes suggests that legal rights and duties should be understood in terms of what will happen should there be a breach: "a legal duty so called is nothing but a prediction that if a man does or omits certain things he will be made to suffer in this or that way by judgment of the court; - and so of a legal right." $"$ He also suggests, at least implicitly, that moral rights and duties cannot be analogously understood.

As an initial point, however, it is not at all clear that Holmes is accurately reflecting how moral rights and duties are understood, at least by John Stuart Mill, who suggests that they also should be understood in terms of what will happen in the event of a breach. Mill argues that "[w]hen we call anything a person's right, we mean that he has a valid claim on society to protect him in the possession of it, either by the force of law, or by that of education and opinion," and that a breach of duty - in other words, a wrong — is something for which "a person ought to be punished in some way or other for doing it; if not by law, by the opinion of his fellow creatures; if not by opinion, by the reproaches of his own conscience." Both Holmes and Mill define rights and duties in terms of what happens in the event of a breach, although Holmes' focus is on legal rights and duties and Mill's focus is on rights and duties more generally.

Even if moral rights and duties and legal rights and duties can all be explicated in terms of what happens when there has been a breach, this hardly establishes that Holmes is incorrect in believing that the two must be distinguished. Holmes suggests that "nothing but confusion of thought can result from assuming that the rights of man in a moral sense are equally rights in the sense of the Constitution and the law." "For example, an individual might have a moral right to do something that the law prohibits, and such a law may be enforced, moral right notwithstanding. Holmes writes that "[n]o one will deny that wrong statutes can be and are enforced," consciences might nonetheless find themselves fined or imprisoned for having broken an immoral law. Thus, commentators are correct that Holmes denies that there is a one-to-one correspondence between moral and legal rights.

Holmes' recognition that the contents of moral and legal rights may diverge hardly entails a strict separation betwcen law and morality," although it does suggest that there can be serious theoretical and practical ramifications if the divergence between law and morality is ignored. Holmes warns of "the danger, both to speculation and to practice, of confounding morality with law, and the trap which legal language lays for us on that side of our way." Because he believes that moral terms obscure rather than clarify legal terms when the terminology overlaps, Holmes argues that there would be a net "gain if every word of moral

Joln Stuart Mill, "Utilitarianism" in J.M. Robson, Collected Works of Jolm Stuart Mill: Essays on Ehics. Religion omed Socien!. vol, 10) (Toronto: University of Toronto Press, 1969) 205 at 250. Ibid. at 246.

Holmes. "The Path of the Law." saymra note 3 at 460 .

bid.

Catharine Peirce Wells, "Oliver Wendell Holmes, Jr., and William James: The Bad Man and the Moral Life" in Burton, suppra note 29, 211 at 220 ("In The Path of the Law, Holmes proposes a strict separation between law and morals. 'Nothing but confusion of thought.' he wams, "can result from assuming that the rights of man in a moral sense are equally rights in the sense of the Constitution and the law."). Holmes. "The Path of the Law." supra note 3 at 464. 
significance could be banished from the law altogether, and other words adopted which should convey legal ideas uncolored by anything outside the law." ${ }^{33}$

Such a pruning of the legal lexicon would not be without cost, since we would "lose the fossil records of a good deal of history and the majesty got from ethical associations. ${ }^{84} \mathrm{He}$ nonetheless argues that such a cost is worth paying because "by ridding ourselves of an unnecessary confusion we should gain very much in the clearness of our thought." ${ }^{.85}$ Basically, Holmes is suggesting that there is an important connection between law and morality but that the benefits of recognizing that connection through the use of common terminology are more than outweighed by the costs of using that common terminology, for example, mistakenly believing that what is morally protected must be legally protected and vice versa.

\section{B. Moral versus legal. Duties}

Holmes makes a point that might also be made by individuals believing in an objective and knowable morality - namely, that morality and the law sometimes diverge. Yet, such a point might be made for a variety of reasons including, for example, to provide a reason to change outdated and anachronistic laws. Thus, Holmes notes that morality and the law are not coextensive because the law does not always keep abreast of changing moral notions. He suggests that "when we speak of the rights of man in a moral sense, we mean to mark the limits of interference with individual freedom which we think are prescribed by conscience, or by our ideal, however reached." law, however. Indeed, "many laws have been enforced in the past, and it is likely that some are enforced now, which are condemned by the most enlightened opinion of the time, or which at all events pass the limit of interference as many consciences would draw it." ${ }^{87}$ Thus, Holmes suggests that there will be instances in which legal sanctions should be imposed as a legal matter because the individual clearly violated the law, even though the legal sanctions should not be imposed as a moral matter because the legal prohibition itself should not exist as a moral matter.

Yet, one's making the point that the law may not keep up with morality hardly makes one a moral nihilist. Even Holmes' discussion of the bad $\operatorname{man}^{\mathrm{kx}}$ is hardly nihilistic or even positivistic, commentators' claims to the contrary notwithstanding.

Consider the following criticism of Holmes: "Holmes disagreed that there were any objective moral truths, a thoroughly positivist argument ... [which] can be seen from his argument that 'a legal duty so called is nothing but a prediction that if a man does or omits certain things he will be made to suffer...'." ${ }^{89}$ Yet, Holmes might believe that there were objective moral truths without defining legal dutics in terms of those truths. For example, in

$\begin{array}{ll}\text { s: } & \text { lbid. } \\ \text { ss } & \text { lbid. } \\ \text { st } & \text { lbid. } \\ \text { so } & \text { lbid. at } 460 . \\ \text { s: } & \text { lbid. } \\ \text { \&. } & \text { See supra notes } 5-10,15-19 \text { and accompanying texi. } \\ \text { sq } & \text { Knudson, supra note I at } 416 \text { [ footnoles omitted]. }\end{array}$


The Province of Iturisprudence Determined," John Austin distinguishes between "nattral law, or ... the law of narwe (meaning, by those expressions, the law of God), [and] the aggregate of the rules, established by political superiors, [which] is frequently styled positive law, or law existing by position." "Austin believes both in a universal, objective moral code established by God and in a positivist, legal code imposing legal duties that may but need not coincide with moral duties." Thus, one who offers a positivist analysis of law and legal duty might nonetheless believe in an objective moral reality. ${ }^{93}$

Those affirming and those denying an objective, knowable, moral reality should recognize the importance and accuracy of Holmes' point that legal rights and duties may differ in content from moral rights and duties. While these theorists might disagree about the implications of such a divergence - some suggesting that moral rights and duties must be respected regardless of what the law dictates ${ }^{94}$ and others suggesting that legal rights and duties must be respected regardless of what morality dictates ${ }^{95}$ - that is a different point that supports rather than undermines the importance of recognizing that divergence.

That moral and legal duties may have different contents does not entail that it would be beneficial to remove any terms having moral import from the legal lexicon. Holmes' claim that there would be a net gain by performing such a pruning does not entail the non-existence of moral truth but merely that the costs incurred in using common terminology are greater than the benefits thereby|accrued. Thus, some of those accepting and some of those rejecting the existence of objective moral truth might believe that such a pruning would be beneficial, while others from each camp might disagree.

A number of factors might be considered when assessing Holmes' cost-benefit calculation regarding whether such a pruning would be worthwhile. One might want to know whether using another term to refer to legal rights would somehow undermine the connection between that which is protected légally and that which is protected morally. If people conflate moral and legal rights out of a belief that the contents of legal rights are determined by the contents

John Austin, The Province of.Aurisprudence Determined (Union. N.J.: The Lawbook Exchange Lid., 1999) (London: John Murray. 1832).

11 Bid. at 2 [cmphasis in original].

42 Austin defines duty in terms of the duty-holder's being subject to punishnent for the failure to perform his duty. Sec ibid. at 7: "Being liable to evil from you if l comply not with a wish which you signify. I am bound or obliged by your command, or I lie under a duty to obey il" [umphasis in original].

To make matters even inore complicated, Austin distinguishes between natural law (the "true" morality) and positive morality. See ibid, at 4: "the name moralin' (or morals), when standing unqualified or alone, denotes indifferently either of the following objects: namely, positive morality as it is, or without regard to its merits: and positive morality as is would be, if it conformed to the law of God" [emphasis in originall.

4s Sec. e.g. John Finnis, "On the Incoherence of Legal Positivism" (2000) 75 Notre Dame L. Rev. 1597 at 1606-607:

Some laws are utterly unjust. utlerly immoral; the lact that something is declared or enacted as law by the social sources authorized or recognized as sources of valid law in no way entails that it is (or is even regarded by anyone as) morally acceptable or is even relevant to a consideration of somtone's moral responsibilities.

Cf. Richard A. Posner, The Problemutics of Moral and Legal Theony (Cambridge, Mass.: Hanard University Pruss, 1999) at 141 ("moral theory has nothing for Iow"); but see ibid. at 143 ("If judges are carefully selected. as is generally truc of federal judges. a judge's civil disobedience - his refusal to enforce a law "as writlen" because it violates his deepest moral feelings - is a significant datum"). 
of moral rights rather than because the term "right" is used in both contexts, then modifying the legal lexicon would not prevent the conflation.

By the same token, suppose that the word "wrong" were reserved for the failure to meet the relevant moral standard and other words were used to describe legal wrongs such as "illegal" or "tortious." Lack of overlapping terminology notwithstanding, individuals might still incorrectly believe that whatever is (morally) wrong is also illegal or tortious. Holmes' pruning suggestion assumes, without establishing, that the terminology itself affects what people believe, that changing the terminology would change the beliefs. If instead the conflation is due to something else, then adopting Holmes' suggestion might not yield the benefits that he envisions.

If, indeed, the terminology itself has an effect on what people believe, one would want to know whether a change in terminology would change the likelihood that legal rights and duties would be respected by societal members or, perhaps, whether the penalties for not respecting those rights and duties would have to be enhanced to induce more compliance. Thus, it might be argued that individuals would be less likely to follow the law were they to feel no moral obligation to do so, and penalties would have to be increased to make up for the lost moral incentive to be law-abiding. Perhaps that is so, although Holmes' example of the bad man is designed to refute that claim. Holmes argued that the current system gives individuals sufficient incentive to act well even bracketing their desires to act morally, and thus that the "majesty got from ethical associations" is not necessary to induce people to follow the law.

Some individuals seem to believe that the law and morality are interrelated at least in the sense that (their perception of) what is morally required must be permitted by the law if only as an exception to the general legal rules. For example, one who sincerely believes the killing of abortion doctors to be morally required might wrongly believe that the law allows such behaviour as an exception to the general laws proscribing murder. ${ }^{97}$ Arguably, more clearly separating moral and legal terminology would make it less likely that individuals would wrongly think that the law would contain such an exception.

Killing a physician who performs abortions might seem to be a poor example for purposes here, since such an act is both illegal and morally wrong. Yet, the illegality of that act is not dependent upon the recognition of its immorality. Indeed, there is no universal agreement about the correct moral evaluation of such a killing, as might be evidenced by some of the comments made by the perpetrators of such acts - some who have committed such murders have gone to their deaths believing that what they did was morally defensible if not morally required. ${ }^{98}$

The point here is not that the murderer's sincerity of belief regarding the moral permissibility of his action somehow makes it so, but merely that an illegal act does not

* Holmes, "The Path ol the Law," supra note 3 at 464.

97 Compare Hill v. Stafe, 688 So.2d 901 (Flu. 1996), affirming a rejection of the necessity defense offered by a man convicted of murdering an abortion clinic physician and a volunteer.

98 Sec, e.g., "US executes abortion killer" Melbourne Heruld Sun (5 September 2003) 39 (abortion doctor murderer untepentant for his act). 
suddenly become legal because of a sincere belief in the act's moral permissibility. That is true even in cases where the perpetrator is correct about the moral quality of his action - as Holmes points out, "[n]o one will deny that wrong statutes can be and are enforced."

A separate question is whether the fact of the action's illegality (and the non-cxistence of an exception to the law against murder which would permit the killing of doctors who perform abortions) would dissuade the would-be murderer from performing the act. It is not at all clear that one who believed that he would be greatly rewarded in heaven for his act ${ }^{(x)}$ would be dissuaded from performing it by the knowledge that it was illegal and that he would be punished in this life for performing it. Thus, even in the kind of case where the person believes in a very close correspondence between law and morality but misunderstands what morality requires or even permits, it is simply unclear whether adopting Holmes' suggestion to prune the legal lexicon to make even clearer that law and morality sometimes diverge would bring about a desired change in behaviour.

Holmes had an intuition that individuals would be less likely to conllate law and morality were the legal terminology changed, and that the clarity thereby achieved would be a net benefit for society notwithstanding the loss of "majesty got from ethical associations." While Holmes can perhaps be criticized for not having offered a more persuasive case for his recommendation, ${ }^{102}$ his recognition that morality and the law do not always overlap and his recommendation that moral terms be removed from the legal lexicon hardly constitute a theory advocating a radical separation between law and morality. Indeed. an individual believing that there is a necessary connection between law and morality as a general matter might nonetheless recognize that some laws are immoral and, further, support a recommendation that legal terminology be changed so that the unwary would not be misled into believing that there is a one-to-one correspondence between moral and legal duties.

\section{HOLMES' MORAI. VIEW}

Commentators are correct that Holmes did not believe in a knowable, objective, universal morality. Yet, commentators fail to place Holmes' moral skepticism ${ }^{103}$ in context and, further, fail to examine the non-implications of that moral skepticism for his theory of law. While Holmes' moral views may not have been well-developed or even coherent. that should not be permitted to undermine his contributions to an understanding of the law.

Holmes, "The Path of the Law," supres note 3 at 460.

See supra note 98 (unrepentant murderer of abortion doctor expected great rewards in heaven).

Holmes, "The Path of the Law," supra note 3 at 464.

It is not at all clear that Holmes was oflering this as a proposal for scrious consideration, so it is not at all clear that he should have oftered the kind of support which a serious proposial would have required. See Michael J. Phillips, "The Substantive Due Proeess Decisions ol'Mr. Justice Holmes" ( I999) 36 Am. Bus. L.J. 437 at 474 (suggesting that Holmes is a moral skeptic). 


\section{A. HOLMES' MORAL SKEPTICISM}

Holmes was sometimes quite acerbic about morality, having once described morals as "the superior politenesses that absorb the shock of force." 104 Yet even here, Holmes' comment is open to a variety of interpretations, ${ }^{105}$ and it is not at all clear that he was dismissing morality as merely something that makes force more palatable. ${ }^{106}$ Indeed, Holmes was quite aware that this description of morality was open to great misunderstanding, and he cautioned that the comment should not be repeated for fear that the necessary accompanying explanation of what he meant would not also be presented. ${ }^{107}$

Commentators' claims notwithstanding, it is not at all clear that Holmes was a moral nihilist, ${ }^{108}$ if only because his comments about morality were not consistent. In a letter, he suggests that morals absorb the shock of force, but elsewhere he offers a much more positive view of morality, suggesting that it has a salutary effect on the way that people behave. ${ }^{109}$

One reason that commentators claim that Holmes did not believe in morality 111 ' is that in a letter, Holmes compared moral views to gustatory preferences, suggesting that

one's own moral and acsthetic preferences ... [are] more or less arbitrary, although none the less dogmatic on that account. Do you like sugar in your coffee or don't you? You admit the possibility of difference and yet are categorical in your own way, and even instinctively condemn those who do not agnee. 'I

Here, Holmes is suggesting that individual moral beliefs, while steadfastly held, are not the sorts of beliefs that are subject to disconfirmation through rational discussion. ${ }^{112}$

104 Robert M. Mennel \& Christine L. Compston, eds., Holmes and Frankfurter: Their Correspondence. 1912-1934 (Hanover: University Press of New England, 1996) at 203 (21 May 1926).

He might have been suggesting. for example, that false claims about what morality requires are sometimes used to justify the enforcement of yuestionable policies.

For such a view, see Pohlman, stupra note 42 at 132 ("Holmes understood morality as a veneer of politeness that hid the ultimale fact of loree").

107 Mennel \& Compston, supra note 104 at 203 ("But this is between ourselves as such a proposition unexplained would be caviare to the general"). Cf. William Shakespeare. /lamket, act II, scene 2, in W.J. Craig, ed., The Complete Works of William Shakespeare (London: Henry Pordes, 1973) 941 at 956 ("the play, I remember, pleas'd not the million; "was caviare to the general").

Cf. Luban, "Judicial Restraint," supra note 2 at 475 , suggesting that Holmes was a kind of moral nihilist. Cf. Holmes, "The Path of the Law," supra note 3 at 459 ("The practice of [morality], in spite of popular jests, tends to make good cilizens and good men").

110 Ilenry Cohen, "Oliver Wendell Holmes Jr.: Life and Philosophy" (2004) 51 Fed. Law. 22 at 24 ("Holmes went further: he denied morality entirely. once comparing moral preferences to a taste for sugar in one's coflee").

II' Mark DeWolfe Howc, ed.. /lolmes-Pollock Letlers: The Correspondence of Mr Justice Holmes and Sir Frederick Pollock. 1874-1932, 2d ed. (Cambridge, Mass.: I larvard Universily Press, 1961) vol. I at 105 (6 Seplember 1902).

11: Luban, "The Bad Man and the Good Lawyer," supra note 16 at 1571: "Holmes doubted that we have a moral obligation to obey the law, but that is only because he doubicd that we have any moral obligations; he was certain that law cannot be deduced rationally from ethical principles; he denied that ethical principles are rational" [emphasis in original]. 
Yet, what is not sufficiently emphasized is that Holmes was not merely offering this skeptical view about morality in particular - he was offering it about truth more generally. In the same letter he suggests:

\begin{abstract}
We tacilly postulate that if others were as intelligent and well educaled as we they would be compelled to agree with us [about truth].... The fact is that each has his more or less diflering system; whether there is an objective reality in which is to be lound the unity of our several compulsions or whether our taste in truth is as arbitrary as our laste in coflee and there is no objective Iruth at all, I leave to philosophers by profession. ${ }^{113}$
\end{abstract}

To understand Holmes' moral view, one must place Holmes' denial of an objective moral truth $^{11+}$ in the context of his denying having knowledge about a whole host of subjects including the existence of other beings. ${ }^{115} \mathrm{Heclassified} \mathrm{himself} \mathrm{as} \mathrm{a} \mathrm{"bettabilitarian} \mathrm{(one} \mathrm{who}$ thinks you can bet about it but not know)."116 For Holmes, truth was not something that was somehow independently verifiable but, instead, something that he simply could not help believing. ${ }^{117}$ Thus, while it is truc that Holmes was not confident of the existence of objective moral truth, it is also true that he was not confident of the existence of any kind of truth. ${ }^{1 / k}$

\title{
B. HOLMES' MORAL Critique
}

Some commentators who condemn Holmes for his alleged amoralism imply that anyone who does not believe as they do must be amoral. For example, Professor Alschuler argues that "Holmes was at the forefront of ... a revolt against objective concepts of right and wrong - a revolt against natural law," 119 as if the only individuals who could believe in an objective right and wrong were those who subscribed to a natural law position. Yet. Mill believed in an objective right and wrong, notwithstanding his rejection of natural law in favour of utilitarianism. Many of the criticisms offered against Holmes are just as applicable

Howe, supra note 111.

Pohlman. supra note 42 at 14 ("Since he had no objective standard of morality, Holmes did not believe in a necessary relationship between ideal systems of "law and morality"); Catharine Wells Hantzis. "Legal Innovation within the Wider Intellectual Tradition: The Pragmatism of Oliver Wendell IJolmes, Jr." (1988) $82 \mathrm{Nw}$. U.L. Rev. 541 at 580 ("Holmes proclaimed himself to be a skeptic with respect to moral questions").

llowe, supra note 111 , vol. 1 at 122 (23 November 1905):

I quite agree that when we decide that our brother is not our dream it is his agrement with us as to chair, table. itc., that makes us surmise that they also are not only our dream — and 1 add that if I admit my brother I don't see why I should not admit the world. Yet as I can't get outside my dream I admit something I don't know. I put it as a mere bet.

lbid., vol. 2 at 22 (21 August 1919).

Bbid., vol. 1 at 126 (23 June 1906) ("I always start my cosmic salad by saying that all I mean by truth is what 1 can' help thinking and that 1 have no means of deciding whether my can't helps have any cosmic worlli").

Oliver Wendell Ilolmes, "Ideals and Doubts" (1915) 10 III. L. Rev. I at 2, as quoted in Novick, sinno" nole 43, 442 at 443 [Holmes. "Ideals and Doubts"]:

When I say that a thing is true. I mean that I cannot help holieving it. I am stating an experience as to which there is no choice. But as there are many things that I cannot help doing that the universe can. I do not venture to assume that my inabilitics in the way of thought are inabilities of the universe. 1 therefore define the truth as the system of my limitations, and leave absolute truth for those who are better equipped. With absolute truth I leave absolute ideals of conducl equally on one side.

See Alschuler, supra note 2. 
to theorists who would self-describe as believers in an objective moral code which happens not to correspond to the preferred moral view of the individual offering the criticism. It thus is sometimes difficult to tell whether Holmes' failure (in the cyes of these commentators) is in his not believing in an objective and universal moral code or in his not sharing their particular moral views. ${ }^{\text {2" }}$

The point here should not be misunderstood. It is hardly surprising that Holmes is criticized severely by those sympathetic to a natural law position, since Holmes is especially critical of natural law. Holmes suggests that the "jurists who believe in natural law seem to me to be in that naïve state of mind that accepts what has been familiar and accepted by them and their neighbors as something that must be accepted by all men everywhere."121 In these observations, Holmes is echoing Mill's observation that the "universal voice of mankind, so often appealed to, is universal only in its discordance. What passes for it is merely the voice of the majority or, failing that, of any large number having a strong feeling on the subject."122 Holmes and Mill object to these claims of universality both because of their factual inaccuracy ${ }^{123}$ and because that alleged universality was offered as proof of the validity of the views being offered. ${ }^{124}$

Holmes complains of the "alliance of philosophy with religion and the dogmatic foothold that it gets from a morality from which to bully nous autres." 125 His discussion of moral bullying and dogmatic footholds suggests that: (1) he disagrees with what is being asserted, since he does not like others attempting to bully him into adopting their position; (2) he believes that those propounding these views offer no justification for that position but instead are offering dogmatic truths, in other words, they are making assertions which have to be accepted on faith; and (3) he believes that these theorists are seeking to impose their views through illicit means (intellectual bullying) rather than persuasion, for example, by pointing out the beneficial effects the adoption of these positions would have. ${ }^{26}$

120 See, e.g., Roben J. Muldoon, Jr., Boak Review of Law without Vahtues: The Life. Work, and Legacy of . Insfice Holmes by Alben W. Alschuler (2002) 86 Mass. L. Rev. 125 at 127 ("Contrary to the tille, Alschuler argues and, to a great extent, demonstrates, that Holmes did indeed operate on a basis of values, but they are neot Alschuler's").

Oliver Wendell Holnes, "Natural L.aw" (1918) 32 Ilarv. L. Rev. 40 al 47, as quoted in Novick, supwa nole 43, 445 at 446 [Holmes. Natural Law"].

12: John Stuart Mill, "Whewell on Moral Philosophy" in Robson, supro note 77, 165 at 194.

133 Robert (ieorge dismisses Holmes' criticisms. See Robert P. George, "I Holmes on Natural Law" (20022003) 15 Regent U.L. Rev. 175 at 184 ("this is plainly a false charge"). Ile then suggests that one of the main points of dispute between Holmes and the Natural Law theorists is whether "people ought to believe and act on the basis of what is true, correct, sound. and warranted," as if this were something to which the Nalural Law Theorist had access in a way which others did nol (ibid. at 186). This is precisely Holmes" point.

i24 Cf. Mennel \& Compston, supra note 104 at 8 (8 April 1913) ("Philosophers are apt to try to retain the dogmalic supremacy formerly accorded to theologians by assuming a mystic infinite value for morality as point d "appmi |point ol support]").

13. Howe, supra note 111 . vol. 1 at 191 (26 April 1912).

130. Holmes viewed morality as a collection of rough generalizations about what would promote the general good. Cf. Holmes, "Ideals and Doubts," supra note 118 at 444 ("Our system of morality is a body of imperfect social generalizations expressed in terms of emotion. To get at its truth, it is useful to omit the emotion and ask ourselves what those generalizations are and how far they are confirmed by fact accurately ascertained."). 
When criticizing these "moral bullies," Holmes is presumably not complaining about the lack of deductive proof for their arguments, since he believes that no one could offer such arguments. ${ }^{127}$ Rather, he is complaining about what he views as intellectual dishonesty, since these theorists claim to be offering reasoned arguments while really making assertions that ultimately are no more rationally established than any other.

Notwithstanding his worries about the way moral positions might be used or abused, Holmes is not dismissing the importance of morality. ${ }^{128}$ He describes law as the "witness and external deposit of our moral life."12\% "Our moral life" does not refer to some universally held position, but instead to the views of society or, perhaps, of a particular subset of society. Holmes accepts that "there is such a body on which to a certain extent civilized men would agree," ${ }^{130}$ although he suspects that even that moral consensus is much narrower than commonly believed. ${ }^{131}$

When Holmes discusses morality, he has in mind "a body of imperfect social generalizations"132 about what would promote the common good, which are "expressed in terms of emotion," ${ }^{* 133}$ in other words, asserted with an air of correctness and certainty. He argues that to determine which generalizations actually promote the common good. it is helpful to discard the emotion, i.e., the steadfastness and certainty about the contents of moral rules, and instead examine the rules and their effects - "it is useful to omit the emotion and ask ourselves what those generalizations are and how far they are confirmed by fact accurately ascertained." 134

This view of morality as imperfect generalizations about what would promote the general good echoes Holmes' understanding of the law - he suggests that the law develops in accord with what will promote the good of the community. "It is perhaps because he views the law and morality as being similar in the sense that he thinks that there is "a wider point of view from which the distinction between law and morals becomes of secondary or no importance." 136

While Holmes believes that law and morality develop in light of what will promote the general good, he nonetheless denies that the law's development is clear and

It is for this reason that Holmes' argument is not sell-reluting in the way somelimes suggested by his critics. Sec Georgi, supra note 123 at 184-85.

Gordon, "The Path of the Lawyer," supra note 12 at 1015:

Take the "bad man" and the "predietion theory." This can't possibly be a theory that law has no moral content. "The law is the witness and external deposit of our moral life," Holmes says in The Path, and elsewhere makes it clear that the law of any age is saturated with "prevalent moral and political theories" as well as "[ $t]$ he felt necessities of the time." Holmes, "The Path of the Law," supra note 3 at 459. Howe, supro note II 1, vol. 2 at 3 (24 January 19/9).

bid. (mentioning the fact of some agreement but then suggesting that the extent of agreement may be much less than was commonly believed - "lhow much less than would have been taken lior granted fifty years ago, wilness the Bolsheviki").

lbid.

Jbid.

Holmes, "Ideals and Doubts," supra note 118 at 444.

Holmes, "The Common Law," supra nole 43 at I33.

Holmes. "The Path of the Law," supra note 3 at 459. 
straightforward. ${ }^{137}$ In "The Common Law," Holmes explains: "[t]he life of the law has not been logic: it has been experience." ${ }^{38}$ He lists a number of factors that determine how the law will develop: the "felt necessities of the time, the prevalent moral and political theories, intuitions of public policy, avowed or unconscious, even the prejudices which judges share with their fellow-men, have had a good deal more to do than the syllogism in determining the rules by which men should be governed." 139 Thus, theories, intuitions, and a host of other clements all play a role in how the law develops, some involving principles and some not. Although the promotion of the good of the community will play an important role in the law's development, ${ }^{140}$ it is simply false that any one principle, even the promotion of the common good, can tully explain that development. While it may be possible to spot a pattern in the law's development, the law does not develop along a straight line. ${ }^{\mid+1}$

Holmes criticizes those who believe that they can deduce the law from abstract principles. ${ }^{42}$ or even those who would claim that the law at the very least is internally consistent. ${ }^{143}$ Indeed, he believes that one of the law's strengths is that it is changing in light of all of these factors and that the law "will become entirely consistent only when it ceases to grow." $" 14$

While the law is quite clear in some cases, it is inuch less so in others, especially because "the law is always approaching, and never reaching, consistency. It is forever adopting new principles from life at one end, and it always retains old ones from history at the other, which have not yet been absorbed or sloughed off."145 Precisely because the law changes in light of a number of factors, ${ }^{146}$ not all of which are articulated or even consciously considered, ${ }^{147}$ prediction of how the law will develop is both difficult and quite important.

Holmes, "The Common L.aw," supra note 43 at 154-55.

libid.

Ibid.

lbid. at 133:

The very considerations which judges most rartly mention, and always with an apology, are the secret root from which the law draws all the juices of life. I mean, of course. considerations of what is expedient for the community concerned. Every important principle which is developed by litigation is in fact and at bottom the result of more or less delinitely understood views of public policy; most generally, to be sure, under our practice and traditions, the unconscious result of instinclive preferences und inarticulate convictions, but none the less traceable to views of public policy in the last analysis.

Sec itid. at 154-55:

The law did not begin with a theory. It has never worked one out. The point from which it started and that at which I shall try to show that it has arrived, are on different planes. In the progress from one to the other, it is to be expected that its course should not be straight and its direction not always visible. All that can be done is to point out a tendency, and to justify it.

Ibid. at 133 ("What has been said will explain the failure of all theories which consider the law only from its formal side, whether they attcmpt to deduce the corpus from a priori postulates").

Ibid. (criticizing those who commit the "humbler crror of supposing the seience of the law to reside in the elegantia juris, or logical tohesion of part with parr").

thid.

thid.

See Oliver Wendell Holmes, "The Bar as a Profiession" in Novick, supra note 43, 386 al 387 ("A system of law at any time is the resultant of present needs and present notions of what is wise and right on the one hand, and, on the other, of rules handed down from carlier states of society and embodying needs and notions which more or less have passed away").

Holmes, "The Path of the Law," supra note 3 at 467. 
One reason that Holmes is sometimes thought to be a moral nihilist who glorifies the strong and powerful is his suggestion that the "first requirement ol" a sound body of law is, that it should correspond with the actual feclings and demands of the community, whether right or wrong." 48 Yet, here Holmes is not glorifying the demands of the most powerful element of the community, ${ }^{149}$ but instead suggesting that if the law does not capture the feelings of the community in important ways. members of the community may well take matters into their own hands. ${ }^{150}$ Indeed, ironically, by positing the possibility of a divergence between the demands of the community and the dictates of morality, Holmes is suggesting that morality is objective and that it does not simply reflect the views of the dominant in society. ${ }^{151}$

Holmes' moral views are not particularly well developed in his writings and, further, are not consistent. He sometimes implies that morality is simply the velvet glove on the iron fist of the law, ${ }^{152}$ and implies at other times that it makes people better than they otherwise would be. ${ }^{153}$ Yet, what tends not to be discussed is that Holmes' discussion of the development of the law is not dependent on whether he believes in an objective morality. Basically, he suggests that a variety of factors, including morality, influence how the law develops. Such a view is consistent with morality having a necessary (but not determinate) connection with law, a contingent connection with law, and no connection with law (insofar as morality is thought to refer to one objective, knowable code). Further, it is also consistent with the view that there is one universal moral code, as well as with the view that each society has its own moral code. While Holmes' moral views may be controversial, it is not at all clear that they in some way undercut the worth or accuracy of his observations about the law.

\section{Conci.usion}

Holmes offers a predictive theory of law that uses the controversial example of a bad man to illustrate the theory. While capturing various insights about the law, the theory is neither as unique nor as destructive as various commentators claim. For example, commentators incorrectly claim that the bad man illustrates the immoral nature of the law. Rather, by using the bad man, Holmes merely illustrates that many individuals will follow the law to avoid adverse legal consequences even if they are not, in addition, induced to follow it out of a recognition of its moral rightness or, perhaps, out of fear that the lailure to abide by the law will result in the imposition of moral sanctions.

145 Holmes, "The Common Law," supra note 43 at 136.

iso Cf. Albert W. Alschuler, "The Descending Trail: Holmes" Path of the Law One Hundred Years Later" (1997) 49 Fla. L. Rev. 353 at 358 ("Onc need only recognize Holmes as the Nietzschean that many of his writings reveal - a figure who not only siw Darwinian stniggle as the order of the universe hul also venerated power, conflict, violence, death, and survival").

Sce Ilolmes, "The Common Law." supra note 43 at 136 (suggesting that it is important to "avoid the greater evil of private retribution").

Cf. Holmes, "Natural Law," supro nole 121 at 446 ("I used to say, when I was young, that truth was the majority vole of thit nation that could lick all others").

Cf. Catharine A. Mackinnon, Feminism Umodiffed: Discourses on Life ond law (Cambridge, Mass.: Harvard University Press, 1987) at 8 ("Difference is the velvet glove on the iron fist of domination"). See Holmes, "The Path of the Law," supra note 3 at 459 ("The practice of [morality], in spite of popular jests, tends to mikt good citizens and good men"). 
Holmes recognizes as a matter of fact that the dictates of the law and morality do not always coincide, and claims that much clarity would be gained if moral and legal terminology did not overlap. Perhaps he is incorrect, for example, because the conflation of law and morality is not due to overlapping terminology, but instead to the societal inculcation of the belief that law reflects or is dependent upon morality. Further, even if clarity would be gained by pruning the legal lexicon of moral terminology, a separate question is whether that increased clarity would have any effect on behaviour and, if so, what that effect would be. Thus, commentators might disagree with Holmes about whether the increased clarity would afford society a net benefit.

Yet, commentators discussing Holmes' views tend not to address whether: (1) Holmes is correct that the law provides sufficient incentive to be law-abiding so that the effects of conscience or public opinion need not be considered; or (2) whether there would be increased clarity were the legal lexicon pruned of moral terms; or even (3) whether such a pruning would have net benefits. They instead overestimate the degree to which he asserts that law and morality should be distinguished, thus distorting his view and the value of his insights. Society and the legal system itself are losers when the insights of one of the foremost American legal theorists are dismissed out of hand because of misrepresentations of his views. Both Holmes and society deserve better treatment than that. 